\title{
Genetic variation and phylogenetic analysis of rabbit haemorrhagic disease virus (RHDV) strains
}

\author{
Beata Hukowska-Szematowicz ${ }^{1 凶}$, Beata Tokarz-Deptuła ${ }^{1}$ and Wiesław Deptuła ${ }^{2}$ \\ 'Department of Immunology, ²Department of Microbiology, Faculty of Biology, University of Szczecin, Szczecin, Poland
}

Rabbit haemorrhagic disease virus (RHDV) belongs to the family Caliciviridae and is the etiological agent of the haemorrhagic disease, also known as rabbit plague. Its genome is a linear single-stranded (ss) RNA of 7437 nucleotides and the capsid is built from a single structural protein VP60. In connection with the discovery of new RHDV strains, there is a constant need to investigate the genetic variation of this virus and perform phylogenetic analyses which may show the evolutionary relationships among the RHDV strains. Studies on the divergence of RHDV have shown that it is genetically quite stable, although recent observations indicate that some new RHDV strains, significantly different from the original RHDV subtype and the new RHDVa subtype, are appearing. These latest findings suggest that a new group of RHDV strains has evolved. The present review summarizes the current knowledge on the genetic variation and the latest achievements in phylogenetic analyses of RHDV strains isolated in various countries.

Key words: RHD virus, genetic variation, phylogenetic analysis, genogroup

Received: 10 October, 2012; revised: 27 November, 2012; accepted: 06 December, 2012; avaialble on-line: 13 December, 2012

\section{INTRODUCTION}

The first epidemic of rabbit haemorrhagic disease (RHD) emerged in China in 1984 (Liu et al., 1984), but nowadays this disease has spread on all continents and is characterized by a very high mortality rate, reaching 100\% (Hukowska-Szematowicz, 2006). 'The RHD virus belongs to the family Caliciviridae and has a genome formed by linear single-stranded (ss) RNA composed of 7437 nucleotides (Meyers et al., 1991; Wirblich et al., 1996; Meyers et al., 2000). The genome comprises two open reading frames (ORF), the longer ORF1 (7034 nucleotides) encodes non-structural viral proteins (vp) vp16, vp23, vp37, vp30, virus protein-genome linked (VPg) and a structural capsid protein-viral protein (VP60); the shorter reading frame ORF2 (353 nucleotides) codes for viral protein VP12 with so far unidentified function (Meyers et al., 1991; Wirblich et al., 1996; Meyers et al., 2000).

At present, the GenBank data base contains sequences of the full genome of 35 RHDV strains, structural capsid protein VP60 for 48 RHDV strains, and 200 different genome fragments of 50 RHDV strains (Annon, 2012). Apart from the sequences listed in the Genbank, additional information concerning the sequences of 65 different RHDV strains can be found in many scientific publications (Fitzner \& Kęsy, 2003; Chrobocińska \& Mizak, 2007; Chrobocińska, 2007; Oem et al., 2009; Paw- likowska et al., 2009; Niedźwiedzka-Rystwej et al. 2009; Pawlikowska et al. 2010; Fitzner et al., 2012). These data are very valuable in the context of their potential use in studies on genetic variation of the RHDV, which together with phylogentic analyses may provide information on the evolutionary relationships among its different strains. Results of these studies have contributed to distinguishing 55 specific RHDV strains, termed antigenic variants (RHDVa), and isolation of one Chinese strain, described as the new antigenic variant, as well as one French strain, known as the new variant of RHDV (Table 1).

\section{GENETIC VARIATION OF RHDV STRAINS}

Until now, sequences of about 240 RHDV strains (including RHDVa) have been analyzed in regard to the genetic variation of the RHD virus. The phylogenetic analyses were based mainly on the alignment of gene sequences (full or fragmentary) coding for the VP60 structural protein and vp30 non-structural one (Milton et al., 1992; Boga et al., 1994; Rasschaert et al. 1995; Gould et al., 1997; Nowotny et al., 1997; Le Gall et al., 1998; Asgari et al., 1999; Moss et al., 2002; Fitzner \& Kęsy, 2003; Le Gall-Recule et al., 2003; Hukowska-Szematowicz, 2006; Matiz et al., 2006; Chrobocińska, 2007; Chrobocińska \& Mizak, 2007; McIntosh et al., 2007; Tian et al., 2007; Abrantes et al., 2008; Forrester et al., 2008; Esteves et al., 2008; Yang et al. 2008; Fitzner, 2009; Hukowska-Szematowicz et al., 2009; Muller et al., 2009; Oem et al., 2009; Fitzner et al., 2012; Wang et al., 2012). Among the cited investigations, the studies by Abrantes et al. (2008) and Forrester et al. (2008) are especially interesting, since they used the whole sequence of the gene encoding VP60 or its fragments and were carried out on 100 RHDV strains collected in Europe, Asia and North America between 1984 and 2005. These studies have revealed that the genetic divergence of RHD virus occurs by recombination, thus it is hypothesized that the haemorrhagic disease outbreak registered in 1984 in China was caused by recombination of the genetic material of RHDV originating from angora rabbits that had been imported from Germany. According to those authors (Abrantes et al., 2008; Forrester et al., 2008) recombination may be the key event in RHD virus evolution. Knowledge of this process, together with identification of positive selection sites, may lead to a better under-

\footnotetext{
$\triangle$ e-mail: beatahsz@gmail.com
}

Abbreviations: $\mathrm{HA}(+)$, haemagglutination activity; $\mathrm{HA}(-)$, lack of haemagglutination activity; ORF, open reading frame; RCV-like, rabbit calicivirus like; RCV-A1, rabbit calicivirus from Australia; RHDV, rabbit haemorrhagic disease virus; RHD, rabbit haemorrhagic disease; RHDVa, antigenic variant of rabbit haemorrhagic disease virus; VP, viral protein; VPg, virus protein-genome linked. 
Table 1. Variants of RHD virus

\begin{tabular}{|c|c|c|c|c|c|}
\hline Variant & RHDV strains & $\mathrm{HA}$ & $\begin{array}{l}\text { GenBank Acces- } \\
\text { sion number }\end{array}$ & $\begin{array}{l}\text { Country of origin/ } \\
\text { Year of identification }\end{array}$ & References \\
\hline \multirow[t]{48}{*}{$\begin{array}{l}\text { Antigenic } \\
\text { variants-RHDVa }\end{array}$} & Triptis & $\mathrm{HA}+$ & Y15442 & Germany, 1996 & Schirrmeier et al., 1999 \\
\hline & Hartsmanndorf & $\mathrm{HA}+$ & Y15425 & Germany, 1996 & Schirrmeier et al., 1999 \\
\hline & Viterbo97(Vt97) & $\mathrm{HA}+$ & EU250331 & Italy, 1997 & Capucci et al., 1998 \\
\hline & Pavia97 (Pv97) & $\mathrm{HA}-$ & EU250330 & Italy, 1997 & Capucci et al., 1998 \\
\hline & 9905RHDVa & $\mathrm{HA}-$ & AJ302016 & France, 1999 & Le Gall-Recule et al.,2003 \\
\hline & 00-Reu & no data & AJ303106 & France, 2000 & Le Gall-Recule et al.,2003 \\
\hline & 01-38RHDVa & $\mathrm{HA}+$ & not registered & France, 2001 & Marchandeau et al., 2005 \\
\hline & $03-24$ & no data & AJ969628 & France, 2003 & Le Gall-Recule et al.,2003 \\
\hline & $\mathrm{RH} 29 / 03$ & no data & AY935974 & Hungary, 2003 & Matiz et al., 2006 \\
\hline & NL2004-1 & no data & DQ296063 & Netherlands, 2004 & Van de Bildt et al., 2006 \\
\hline & NL2004-2 & no data & DQ296064 & Netherlands, 2004 & Van de Bildt et al., 2006 \\
\hline & NL2004-3 & no data & DQ296065 & Netherlands, 2004 & Van de Bildt et al., 2006 \\
\hline & ROK & $\mathrm{HA}+$ & not registered & Poland, 2003/2004 & Fitzner et al., 2012 \\
\hline & GRZ & $\mathrm{HA}+$ & not registered & Poland, 2003/2004 & Fitzner et al., 2012 \\
\hline & CB & $\mathrm{HA}+$ & not registered & Poland, 2003/2004 & Fitzner et al., 2012 \\
\hline & ZKA (L4) & $\mathrm{HA}+$ & not registered & Poland, 2003/2004 & Fitzner et al., 2012 \\
\hline & KRY & $\mathrm{HA}+$ & not registered & Poland, 2003/2004 & Fitzner et al., 2012 \\
\hline & ZDU (L1-L6) & $\mathrm{HA}+$ & not registered & Poland, 2003/2004 & Fitzner et al., 2012 \\
\hline & L145/04 & no data & not registered & Poland, 2004 & Chrobocińska \& Mizak, 2007 \\
\hline & W147/05 & no data & not registered & Poland, 2005 & Chrobocińska \& Mizak, 2007 \\
\hline & DCE (L1) & $\mathrm{HA}+$ & not registered & Poland,2006 & Fitzner et al., 2012 \\
\hline & NJChina1985 & no data & AY269825 & China, 1985 & $\begin{array}{l}\text { Mclntosh et al., 2007; Tian et al., } \\
\text { 2007; Wang et al., } 2012\end{array}$ \\
\hline & JXCHA97 & no data & DQ205345 & Chiny, 1997 & $\begin{array}{l}\text { Mclntosh et al., 2007; Tian et } \\
\text { al., } 2007\end{array}$ \\
\hline & TP & no data & AF453761 & China, 2002 & $\begin{array}{l}\text { Mclntosh et al., 2007; Tian et al., } \\
\text { 2007; Wang et al., } 2012\end{array}$ \\
\hline & HYD & no data & JF412629.1 & China 2005 & Wang et al., 2012 \\
\hline & XJ/China/2002 clone 2 & no data & GU339229.1 & China 2002 & Wang et al., 2012 \\
\hline & XJ/China/2002 clone1 & no data & GU339228 & China 2002 & Wang et al., 2012 \\
\hline & $C D$ & no data & AY523410 & China, 2004 & $\begin{array}{l}\text { Mclntosh et al., 2007; Tian et } \\
\text { al., } 2007\end{array}$ \\
\hline & WHNRH & $\mathrm{HA}+$ & DQ280493 & China, 2005 & $\begin{array}{l}\text { Mclntosh et al., 2007; Wang et } \\
\text { al., } 2012\end{array}$ \\
\hline & WHN-1 & $\mathrm{HA}-$ & DQ069280 & China, 2005 & $\begin{array}{l}\text { Mclntosh et al., 2007; Tian et al., } \\
\text { 2007; Wang et al., } 2012\end{array}$ \\
\hline & WHN-2 & $\mathrm{HA}-$ & DQ069281 & China, 2005 & $\begin{array}{l}\text { Mclntosh et al., 2007; Tian et al., } \\
\text { 2007; Wang et al., } 2012\end{array}$ \\
\hline & WHN-3 & $\mathrm{HA}-$ & DQ069281 & China, 2005 & $\begin{array}{l}\text { Mclntosh et al., 2007; Tian et } \\
\text { al., } 2007\end{array}$ \\
\hline & $\mathrm{YL}$ & $\mathrm{HA}+$ & DQ530363 & China, 2006 & $\begin{array}{l}\text { Mclntosh et al., 2007; Tian et al., } \\
\text { 2007; Wang et al., } 2012\end{array}$ \\
\hline & SH/China & no data & FJ794179 & China, 2006 & Wang et al., 2012 \\
\hline & TC/China/2007 & no data & JN165233 & China, 2007 & Wang et al., 2012 \\
\hline & WF/China & no data & FJ794180.1 & China, 2007 & Wang et al., 2012 \\
\hline & NJ-2009 & no data & HM623309.1 & China ,2009 & Wang et al., 2012 \\
\hline & FP/China/2009 & no data & JN165235 & China, 2009 & Wang et al., 2012 \\
\hline & BJ/China/2009 & no data & JN165236 & China, 2009 & Wang et al., 2012 \\
\hline & 09-SD & no data & GU564448 & China, 2010 & Wang et al., 2012 \\
\hline & $\begin{array}{l}\text { RHDVHokkaido/2002/ } \\
\text { JPN }\end{array}$ & no data & AB300693.2 & Japan, 2002 & Wang et al., 2012 \\
\hline & 06Q48-2 & no data & not registered & Korea, 2006 & Oem et al., 2009 \\
\hline & 06D32-1 & no data & not registered & Korea, 2006 & Oem et al., 2009 \\
\hline & 06D106-1 & no data & not registered & Korea, 2006 & Oem et al., 2009 \\
\hline & 06Q755-1 & no data & not registered & Korea, 2006 & Oem et al., 2009 \\
\hline & 07Q92-1 & no data & not registered & Korea, 2007 & Oem et al., 2009 \\
\hline & $08 Q 221$ & no data & not registered & Korea, 2008 & Oem et al., 2009 \\
\hline & $08 Q 712$ & no data & not registered & Korea, 2008 & Oem et al., 2009 \\
\hline
\end{tabular}




\begin{tabular}{|c|c|c|c|c|c|}
\hline & 08Q121 & no data & not registered & Korea, 2008 & Oem et al., 2009 \\
\hline & KV0801 & no data & FJ212322 & Korea, 2008 & Oem et al., 2009 \\
\hline & lowa2000 & $\mathrm{HA}+$ & AF258618 & USA, 2000 & Mclntosh et al., 2007 \\
\hline & NY01 & no data & EU003581 & USA, 2001 & Mclntosh et al., 2007 \\
\hline & UT01 & no data & EU003582 & USA, 2001 & Mclntosh et al., 2007 \\
\hline & IN05 & no data & EU003578 & USA, 2005 & McIntosh et al., 2007 \\
\hline & CUB5-04 & no data & DQ841708 & Cuba, 2004 & Farnos et al., 2007 \\
\hline $\begin{array}{l}\text { New RHDVa } \\
\text { variant }\end{array}$ & XA/China/2010 & $\mathrm{HA}+$ & JN165234 & China, 2010 & Wang et al., 2012 \\
\hline $\begin{array}{l}\text { New RHDV } \\
\text { variant }\end{array}$ & French RHD variant & no data & not registered & France, 2010 & Le Gall-Recule et al., 2011 \\
\hline
\end{tabular}

standing of interactions between the pathogen and its host (Hurst, 2009). Esteves and co-workers (2008), who investigated the positive selection occurring in genes of RHDV strains, have suggested that this process is connected with antigenic regions of the virus. This indicates that the variation among viral strains is caused by the immune response of the host, and is connected with the RHDV pathogenicity and virulence.

Other studies from Australia, China, Czech Republic, France, Italy, Ireland, Korea, Mexico, New Zealand, Poland, Spain and the USA concerning the genetic variation over 100 RHDV strains have shown that it is $14 \%$ (Milton et al., 1992; Boga et al., 1994; Rasschaert et al. 1995; Gould et al., 1997; Nowotny et al., 1997; Le Gall et al., 1998; Asgari et al., 1999; Moss et al., 2002; Fitzner \& Kęsy, 2003; Hukowska-Szematowicz, 2006; Le GallRecule et al., 2003; Matiz et al., 2006; Chrobocińska, 2007; Chrobocińska \& Mizak, 2007; McIntosh et al., 2007; Tian et al., 2007; Yang et al. 2008; Fitzner, 2009; HukowskaSzematowicz et al., 2009; Muller et al., 2009; Oem et al., 2009; Wang et al., 2010; Fitzner et al., 2012), whereas the divergence within the antigenic variants RHDVa ranges between 9.9\% and 10.3\% (Le Gall et al., 1998; Le GallRecule et al. 2003; Chrobocińska \& Mizak, 2007; McIntosh et al., 2007; Fitzner, 2009; Oem et al., 2009; Wang et al., 2010; Fitzner et al., 2012). Another recent estimation done by Le Gall-Recule et al. (2011), who investigated 125 RHDV strains, showed that genetic variation amounting to $14.3 \%$. Additionally this study has revealed a new RHDV strain, called French RHDV variant.

\section{PHYLOGENETIC ANALYSES OF RHDV STRAINS}

Phylogenetic analyses and phylodynamics of RHDV strains have been extensively conducted by many research groups around the world, resulting is the classing of strains into genetic groups, genogroups, lineages and clades (Table 2). The first phylogenetic study was done by Nowotny and co-workers (1997) and comprised RHDV strains collected in the years 1987-1995 from Europe, Asia and North America. It was based on an analysis of a gene fragment coding for VP60 protein and classified the RHDV strains into three separate groups. The first group consisted of RHDV strains isolated between 1989 and 1995 in Europe and Asia, the second comprised European strains from years 1990-1995, and the third group contained European strains from years 1987-1993. The obtained results indicated that the strains were classified according to the temporal, rather than geographical structure. Further studies of Le Gall and co-workers (Le Gall et al., 1998; Le Gall-Recule et al., 2003) performed on French RHDV strains (isolated in 1998-1995 and 1993-2000) and other strains from
Europe were based on an analysis of gene fragments of VP60 and p30 protein. The earlier investigation determined three genogroups (G1-G3), while the more recent study (Le Gall-Recule et al., 2003), in which five RHDVa strains were also included, distinguished six genogroups (G1-G6) classified in accordance to the year of virus collection. Interestingly, all five RHDVa strains (99-05, 00-Reu, Triptis, Hartmannsdorf and Iowa) fell into the G6 genogroup. Even more groups were identified by researchers working on British RHDV strains and samples collected between 1950 and 1980 (Moss et al., 2002). That phylogenetic analysis, also based on an alignment of VP60 gene fragment, classified the investigated strains and samples into eight genogroups, however, the distribution was connected with the site of their isolation rather than the time of collection, and the $8^{\text {th }}$ group contained the RHDVa strains.

A phylogenetic study on Polish RHDV strains (SGM, KGM, PD, MAŁ, BLA, GSK, ŻD, ŻD1 and LUB) collected between 1988 and 2000 was performed by Fitzner and Kęsy (2003). The study was based on the nucleotide sequence encoding the N-terminal fragment of VP60, and a fragment of p30 gene sequence. The analysis divided the strains into two genetic groups, showing temporal similarities; however, the Iowa RHDVa strains from the GenBank formed a separate genetic group. A phylogenetic study performed by Forrester et al. (2003) concerning New Zealand strains isolated in 1997 and other RHDV strains from Europe and USA. Those strains formed only two groups, of which one was phylogenetically related to the Czech strain V-351, and the second genogroup was significantly distinct from it. Furthermore, the second group included the RHDVa antigentic variants (Hartmannsdorf, Triptis, 99-05, ChinaTP, Iowa and France00), which differed phylogenetically from the other investigated strains.

Next, a study by Matiz and co-workers (2006) concerning Hungarian strains isolated between 1988 and 2003 classified those strains on the basis of the VP60 gene. The strains were grouped according to the time of their isolation and identification, however, the third group included phylogenetically distinct RHDVa strains: Hugarian-RH29/0 as well as 99-05, Triptis and 00-Reu. In the same year another work by Forrester and co-workers (2006b) described results of a phylogenetic analysis of RHDV strains collected between 1984 and 2005, based on the sequence encoding VP60. The authors distinguished seven groups. Interestingly, the second genogroup included Irish strains whose position on the phylogenetic tree indicated that there was a single introduction of the RHD virus to Ireland, after which the virus was able to spread before its virulent form was finally identified in 1995. The seventh group 
Table 2. Phylogenetic studies of RHDV strains

\begin{tabular}{|c|c|c|}
\hline Number of strains analysed and their origin & Strain distribution & References \\
\hline $\begin{array}{l}44 \text { from Austria, Germany, France, Spain, Belgium, Hungary, Czech Re- } \\
\text { public, Israel, Slovakia, Ireland, Sweden, Switzerland, Finland, Mexico, } \\
\text { United Kingdom, USA China, Korea }\end{array}$ & 3 genetic groups & Nowotny et al., 1997 \\
\hline $\begin{array}{l}\text { 61, including } 56 \text { from France; others from Czechoslovakia, Italy, Ger- } \\
\text { many, Spain }\end{array}$ & 3 genogroups & Le Gall et al., 1998 \\
\hline $\begin{array}{l}\text { 119, including } 104 \text { from France; others from Czechoslovakia, Germany, } \\
\text { Italy, Spain, United Kingdom, USA, Mexico }\end{array}$ & 6 genogroups & Le Gall-Recule et al., 2003 \\
\hline $\begin{array}{l}\text { 61, including } 45 \text { from the United Kingdom; others from Germany, Italy, } \\
\text { USA }\end{array}$ & 8 groups & Moss et al., 2002 \\
\hline $\begin{array}{l}\text { 14, including } 9 \text { from Poland, others from Czechoslovakia, France, Ger- } \\
\text { many, Italy and the USA }\end{array}$ & 2 genetic groups & Fitzner \& Kęsy, 2003 \\
\hline $\begin{array}{l}\text { 78, including } 38 \text { from New Zealand; others from Germany, France, } \\
\text { Spain, USA }\end{array}$ & 2 groups & Forrester et al., 2003 \\
\hline 37, including 27 from Hungary; others from France and Germany & 3 genogroups & Matiz et al., 2006 \\
\hline 71 strains from Germany, France, China, New Zealand, Mexico & 7 groups & Forrester et al., 2006b \\
\hline $\begin{array}{l}\text { 61, including } 2 \text { from Saudi Arabia and Bahrain; others from Germany, } \\
\text { France, China, Mexico, USA }\end{array}$ & 3 groups & Forrester et al., 2006a \\
\hline $\begin{array}{l}\text { 24, including } 3 \text { from the Netherlands; others from the Czech Republic, } \\
\text { Germany, France, Mexico, China, Ireland, USA }\end{array}$ & 6 genogroups & Van de Bildt et al., 2006 \\
\hline $\begin{array}{l}\text { 43, including } 18 \text { from Poland; others from Germany, France, Spain, Italy, } \\
\text { China and the USA }\end{array}$ & 6 genogroups & $\begin{array}{l}\text { Chrobocińska, 2007; Chrobocińska } \\
\text { \& Mizak, } 2007\end{array}$ \\
\hline $\begin{array}{l}45 \text { from Germany, France, Spain, Italy, Czechoslovakia, China, USA, Cen- } \\
\text { tral America }\end{array}$ & 2 groups & McIntosh et al., 2007 \\
\hline 14 from Czechoslovakia, Germany, USA, Bahrain, Italy, France & 4 genetic groups & $\begin{array}{l}\text { Hukowska-Szematowicz et al., } \\
2009\end{array}$ \\
\hline 4 from the United Kingdom, Germany, Spain, Italy & 2 genetic groups & Niedźwiedzka-Rystwej et al. 2009 \\
\hline 11 from Germany, Hungary, Saudi Arabia, Spain, USA & 2 genetic groups & Pawlikowska et al., 2009 \\
\hline $\begin{array}{l}\text { 66, including } 45 \text { from the Iberian Peninsula (Spain and Portugal); others } \\
\text { from France, Germany, Czechoslovakia, China, Mexico, Saudi Arabia }\end{array}$ & 3 groups/6 genogroups & Muller et al., 2009 \\
\hline $\begin{array}{l}145 \text { samples, including } 71 \text { from the Iberian Peninsula; others from Fran- } \\
\text { ce, United Kingdom, Germany, China }\end{array}$ & 3 lineages & Alda et al., 2010 \\
\hline $\begin{array}{l}217 \text { from various continents :Europe, Asia, America, Australia and Ocea- } \\
\text { nia }\end{array}$ & 4 groups & Kerr et al., 2009 \\
\hline 16 from France & 4 genetic groups & $\begin{array}{l}\text { Hukowska-Szematowicz \& Deptu- } \\
\text { ła, } 2010\end{array}$ \\
\hline $\begin{array}{l}29 \text { from Germany, France, Italy, Spain, USA, China, Australia, Bahrain, } \\
\text { Mexico }\end{array}$ & 4 clades & Kinneart \& Linde, 2010 \\
\hline $\begin{array}{l}46 \text { from Czechoslovakia, Hungary, France, Spain, United Kingdom, } \\
\text { Germany, USA, Mexico }\end{array}$ & 6 genogroups & Pawlikowska et al., 2010 \\
\hline $\begin{array}{l}\text { 34, including } 15 \text { from Poland; others from Germany, China, Italy, Cze- } \\
\text { choslovakia, the USA }\end{array}$ & 3 genetic groups & Fitzner et al., 2012 \\
\hline $\begin{array}{l}\text { 44, including } 21 \text { from China; others from Japan, Italy, Germany, France, } \\
\text { Spain, USA, Mexico }\end{array}$ & 6 genogrups & Wang et al., 2012 \\
\hline $\begin{array}{l}14 \text { RHDV from Germany, France, Spain, China, USA ; } 4 \text { RCV-like from } \\
\text { Italy, United Kingdom; } 1 \text { RCV-A1 from Australia }\end{array}$ & 3 genetic groups & $\begin{array}{l}\text { Strive et al., 2009; Strive et al., } \\
2010\end{array}$ \\
\hline 93 RHDV strains, 32 RHDVa, 4 RCV strains and 36 RCV-A1 & 3 genogroups & Le Gall-Recule et al., 2011 \\
\hline
\end{tabular}

was formed by RHDVa strains Hartmannsdorf, Triptis, 99-05, ChinaTP, Iowa, France00, China and China 1985, phylogenetically very distinct from other analyzed European, Chinese, New Zealand and Mexican strains. In another study of those authors (Forrester et al., 2006a) two strains identified in 2005 from Saudia Arabia and Bahrain were studied. A comparison of those strains with others from the GenBank, showed three groups. The Bahrain strain was located in the second group, indicating its European origin, as this genogroup contained mainly European strains. On the other hand, the Saudi Arabian strain was classified into the third group, which proved its relation with the Chinese strain isolated in 1984, and its phylogenetic relationship with the Czech strain V-351. The third group comprised also the RHDVa strains: Hartmannsdorf, Triptis, 99-05, ChinaTP, Iowa, France00, China and China 1985, proving the genetic distance of these strains from other European lineages examined in this study. Those results were in agreement with other published reports (Moss et al., 2002; Forrester et al., 2003; Forrester et al., 2006b; Muller et al., 2009). 
A phylogenetic analysis based on the VP60 gene sequence was also performed on Dutch RHDV strains collected in 2004 (Van de Bildt et al., 2006). The analysis divided the strains into six genogroups. The three Dutch RHDV strains localized in group 5 on the phylogenetic tree together with French strain 00-13, indicating their common origin. Once again, in that study the RHDVa strains formed a separate group 6. In 2007, another researches (Chrobocińska, 2007, Chrobocińska \& Mizak, 2007) presented results of a phylogenetic analysis of partial capsid protein gene of RHDV strains isolated between 1993 and 2005 in Poland. The Polish RHDV strains (S1/93, S13/94, T20/94, Sz25/94, R45/94, Z73/94, K80/95, Z82/95, B84/95, S86/95, T90/96, Z94/96, S113/97, T116/97, Z118/97, W142/04, L145/04 and W147/05) were localized in four out of six genogroups. It is worth noting that two Polish strains L145/04 and W147/05, were classified into the 6th genogroup, containing other RHDVa strains. A detailed phylogenetic analysis of RHDV strains identified between 1984 and 2005 was done by McIntosh et al. (2007). The analysis, also based on the gene sequence of VP60, identified two distinct groups. The first group contained 26 RHDV strains, described as the original RHDV subtype (Italy90, FRG, Eisenhuttenstadt, Frankfurt, Meiningen, Wriezen, Hagenow, SD, Haute88, 95-05, 00-13, 95-10, 00-08, New Zealand, V-351, Mexico89, WX84, Korea90, Saudia Arabia, Bahrain, AST89, Ireland18, Ireland19, Ireland12, Rainham and BS89). The second genogroup consisted of 19 strains of the new RHDVa subtype (99-05, IA00, WHN3, YL, IN05, 03-24, JXCH97, TP, WHN2, WHNRH, CUB5-04, CD, NY01, WHN1, 00Reu, NJ1985, UT01, Triptis and Hartsmanndorf).

Another phylogenetic study, based on the nucleotide sequence of the gene encoding the p30 non-structural protein, was performed by Hukowska-Szematowicz and co-workers (2009). The cited studies have revealed that these strains can be classified into four genetic groups in regard to the collection period. The nucleotide sequence of an N-terminal fragment of VP60 capsid protein was used by Niedźwiedzka-Rystwej and co-workers (2009), who analyzed four European strains isolated between 1989 and 2000 and showed that they can be grouped into two distinct genetic groups according to the time of their identification. A similar study was presented by Pawlikowska et al. (2009), who investigated RHDV strains isolated in 1989-2002 in Europe. The analysis was based on an alignment of nucleotide sequence of $\mathrm{N}$ and C-terminal fragments of VP60 protein. In that case two genetic groups were identified, and the division correlated with the geographical localization, but was independent of the analyzed fragment of VP60 protein.

Another phylogenetic study based on the sequence of the VP60 gene was performed on RHDV strains isolated in the Iberian Peninsula in 1994-2007 (Muller et al., 2009) and strains from other regions of Europe and the world. The analyzed strains formed three distinct groups (IB1-3), classified in accordance with the time of collection. The groups IB1 and 2 included strains indentified in the years 1994-1997, while strains isolated in 2000-2007 were found in group IB3. Forty remaining RHDV strains underwent additional classification into six genogroups, also divided according to the time of identification, with an exception of genogroup 6, which contained the RHDVa strains (CUB5-04, 9905 and 0324) very distinct from the rest of the investigated strains isolated on the Iberian Peninsula. A similar investigation was presented by Alda and co-workers (2010), who analyzed samples from wild rabbits originating from the
Iberian Peninsula and other strains from the GenBank, collected between 1984 and 2000. It was noted that the analyzed strains form three distinct lineages (I, II, III), and all strains from the Iberian Peninsula were included in lineage I; however, the exact geographical region of origin could not be identified. Nevertheless, those strains shared a similar temporal structure, except for strains from group IB3, containing the most divergent RHDV strains in regard to their time and place of identification. This study also showed that the 12 RHDVa strains (03France, 05China, 88China, 05China, 85China, 05China, 00Reu, 99France, 97China, 98 China, 00USA and 96 German) were grouped into a distinct lineage lineage III.

The most comprehensive phylodynamic study was performed by Kerr and co-workers (2009). The analysis was based on the complete, as well as fragmentary nucleotide sequence of the VP60 gene and included RHDVa strains collected between 1984 and 2008 on different continents. Four distinct phylogenetic groups (G1-G4) were identified, and the obtained classification divided the strains according to the time and place of identification. The first group G1, included RHDVa strains from Cuba, Korea, China, Japan, Great Britain, and continental Europe. The second group G2 comprised strains isolated on the Iberian Peninsula, in France and Germany. Those RHDV strains were genetically and geographically very distinct from all the other strains identified in years 1989-1997, which localized in groups G1, G3 and G4. The next phylogenetic group G3 was formed by old RHDV strains identified in the year of the first outbreak of haemorrhagic disease in Asia (strain WXChina-1984), Europe and Mexico. This group also contained strains collected more recently in New Zealand (2003) and Australia (2005-2006). Group G4 was the most numerous, containing strains indentified between 1989 and 2004 in central Europe, as well as in France, Belgium, the Netherlands, Great Britain, Ireland and Bahrain. Those groups differed in terms of their phylodynamic patterns. However, groups G1, G3, and G4 showed similarities in the obtained patterns, while G2 represented strains with low genetic variation, especially those originating from Spain and Portugal. A phylogenetic study was then performed on French RHDV strains from years 19922005 on the basis of sequence coding for a C-terminal fragment of VP60 protein (Hukowska-Szematowicz \& Deptuła, 2010). The analyzed RHDV strains were classified into four genetic groups, formed in regard to their geographical localization and time of virus isolation.

Yet another study (Kinneart \& Linde, 2010) based on the VP60 gene sequence of different RHDV strains collected between 1984-2006 divided the investigated strains into four distinct monophyletic clades (A-D) showing little geographical and temporal structure. Clade A contained mainly old RHDV strains from France, Germany, Mexico, the Czech Republic and Slovakia, however, the more recently discovered strains from Australia and Saudi Arabia were also located in this group. Clade B was formed by French, German, English, Italian and Bahrain strains, clade C comprised RHDV strains from Germany, Spain, and France, and clade D was formed by RHDVa strains isolated in Germany, China, France and the USA. On the basis of the obtained results the authors concluded that rapid antigenic selection had played a significant role in the evolution of RHDV, and might have been a factor promoting genetic variation during evolution. A phylogenetic study performed by Pawlikowska and co-workers (2010) concerned RHDV strains from years 1984-2004. That comparison classified the ana- 
lyzed strains into six genogroups, localizing the classical RHDV strains into groups $1-5$ according to their time of collection, whereas the $6^{\text {th }}$ genogroup comprised RHDVa strains. A recent phylogenetic study was presented by Fitzner and co-workers (2012). The object of the research were Polish RHDV strains of the period 19882004 and strains from other countries, and the coding sequence of the VP60 gene was compared. The phylogenetic analysis resulted in three genetic groups. The first group contained old RHDV strains identified in the first decade after the discovery of the rabbit haemorrhagic disease. Among those strains two Polish RHDV strains KGM (1988) and MAE (1994) localized together with the classic Chinese strain from 1984, German FRG89, French SD89, Spanish 89, and Czech V351-1987. The second group comprised Polish RHDV strains OPO and LBN (2004), GSK (1998), POZ (1999), ZD0 (2000) and BLA (1994), as well as Italian BS89, German-Frankfurt, and English-Rainham. The third group was formed by RHDVa, including seven Polish antigenic variants $C B$, DCE, GRZ, KRY, ROK, ZDU and ZKA.

The sequence of the gene encoding VP60 was also used in a phylogenetic analysis of Chinese strains collected between 1984 and 2010 (Wang et al., 2012). All the strains included in the analysis were classified into six genogroups (G1-G6) showing common identification period, with the exception of the G6 group that contained all analyzed RHDVa strains. Furthermore, the Chinese strains were localized in genogroups G2 and G6, among which four subgroups were additionally distinguished (CH1-CH4). This pattern of phylogenetic classification indicates that the Chinese strains underwent independent evolution, resulting in identification of a new Chinese RHDVa variant, XA/China/2010, included in the CH4 subgroup.

Another study worth noting in the context of the latest achievements in the phylogenetic analysis of RHDV was performed by Strive and co-workers (2009, 2010). The analysis involved different lagoviruses RHDV, RHDVa, rabbit caliciviruses-like (RCV-like) and rabbit calicivirus from Australia (RCV-A1), based on a subfragment of the capsid protein nucleotide sequence. The analyzed lagoviruses formed three genetic groups, of which the first contained the RHDV and RHDVa strains, the second was formed by RCV-like and the third grouped an Australian nonpathogenic lagovirusRCV-A1. These results were confirmed by a recent study by Le Gall-Recule et al. (2011), who analyzed the sequence of RHDV strains, RHDVa, RCV and RCV-A1. Their phylogenetic analysis also divided the investigated strains into three genogroups, localizing the RHDV and RHDVa strains in the first group, the RCV strains in the second, and RCV-A1 strains in the third group, which included the nonpathogenic Australian lagovirus.

\section{SUMMARY}

Since the time of RHDV identification there has been a constant need to study the genetic variation of this calcivirus and determine its evolutionary pathways. It has been shown that the RHDV is a good model to investigate the divergence and evolution of RNA viruses, as new strains of this virus are constantly appearing in nature. The development of modern methods and bioinformatics techniques allowing transformation of biological observations into mathematical data creates new possibilities of studying the evolutionary relationships among RHDV strains and determining genogroups to identify the lineages and phylogenetic tree topologies of the strains. Studies on the RHD virus divergence have revealed that this virus shows quite high genetic stability, although observation of Le Gall-Recule and co-workers (2011) indicate that new RHDV strains have started to appear. These strains differ significantly from the original RHDV subtype and the new RHDVa subtype, suggesting that a new, distinct group of RHDV strains has been formed. The phylogenetic analyses have shown that the RHDV strains are grouped into lineages according to the time of collection and geographical localization. Furthermore, the strains described as antigenic variants (new RHDVa subtype) are evolutionarily distinct from the original RHDV subtype, which is manifested by an independent localization of their genogroups. It should also be noted that, due to the increasing number of indentified RHDV strains, modern phylogenetic analyses concern not only their genetic origin, but also allow us to indicate the evolutionary relationships among the genogroup thanks to phylodynamic studies. Phylodynamics enables one to recreate changes in the pattern of viral sequence divergence, which allows describing the pattern of virus transfer.

\section{Acknowleddgments}

This work was supported by grant N N308 289937 from the National Science Centre (Poland).

\section{REFERENCES}

Abrantes J, Esteves PJ, van der Loo W (2008) Evidence for recombination in the major capsid gene VP60 of the rabbit haemorrhagic disease virus (RHDV). Arch Virol 153: 329-335.

Alda F, Gaitero T, Suarez M, Merchan T, Rocha G, Doadrio I (2010) Evolutionary history and molecular epidemiology of Rabbit haemorrhagic disease virus in the Iberian Peninsula and Western Europe. BMC Evolutionary Biology 10: 347 (doi: 10.1186/1471-2148/10/347).

Annon (2012) GenBank, National Center of Biotechnology Information, Pub Med (www.ncbi.nlm.nih.gov/pubmed/) (date of the last check 6.07.2012).

Asgari S, Hardy JRE, Cooke BD (1999) Sequence analysis of rabbit haemorrhagic disease virus (RHDV) in Australia: alterations after its release. Arch Virol 144: 135-145.

Boga JA, Casais R, Marin MS, Martin-Alonso JM, Carmenes RS, Prieto M, Parra F (1994) Molecular cloning, sequencing and expression in Escherichia coli of the capsid protein gene grom rabbit haemorrhagic disease virus (Spanish isolate AST/89). J Gen Virol 75: 2409-2413.

Capucci L, Fallacara F, Grazioli S, Lavazza A, Pacciarini ML, Brocchi E (1998) A further step in the evolution of rabbit hemorrhagic disease virus: the appearance of the first consistent antigenic variant. Virus Res 58: 115-126.

Chrobocińska M (2007) The phenotypic and genetic characteristic of national strains of European brown hare virus (EBHS) and rabbit haemotthagic disease virus (RHDV). Habilitation dissertation. National Veterinary Research Institute, Puławy, Poland (in Polish).

Chrobocińska M, Mizak B (2007) Phylogenetic analysis of partial capsid protein gene of rabbit haemorrhagic disease virus (RHDV) strains isolated between 1993 and 2005 in Poland. Bull Vet Inst Pulawy 51: 189-197.

Esteves PJ, Abrantes J, Carneiro M, Muller A, Thompson G, van der Loo W (2008) Detection of positive selection in the major capsid protein VP60 of the rabbit haemorrhagic disease virus (RHDV). $V_{i}$ rus Res 137: 253-356.

Farnos O, Rodriquez D, Valdes O, Chiong M, Parra F, Toledo JR, Fernandez E, Lleonart R, Suarez M (2007) Molecular and antigenic characterization of rabbit hemorrhagic disease virus isolated in Cuba indicates a distinct antigenic subtype. Arch Virol 152:1215-1221.

Fitzner A (2009) Characterization and immunogenetic properties of Polish strains of RHD virus. Bull Vet Inst Pulawy 53: 575-582.

Fitzner A, Kęsy A (2003) Variability of Polish isolates of the RHD virus. Medycyna Wet 59: 905-908 (in Polish).

Fitzner A, Niedbalski W, Paprocka G, Kęsy A (2012) Identification of Polish RHDVa subtype strains based on the analysis of a highly variable part of VP60 gene. Pol J Vet Sci 15: 21-29.

Forrester NL, Abubakr MI, Abu Elzein EME, al-Afaleq AI, Housawi FMT, Moss SR, Turner SL, Gould EA (2006a) Phylogenetic analysis of rabbit haemorrhagic disease virus from the Arabian Penisula: 
Did RHDV emerge simulataneously in Europe and Asia? Virology 344: 277-282.

Forrester NL, Boag B, Moss SR, Turner SL, Trout RC, White PJ, Hudson PJ, Gould EA (2003) Long-term survival of New Zealand rabbit haemorrhagic disease virus RNA in wild rabbits, revealed by RT-PCR and phylogenetic analysis. J Gen Virol 84: 3079-3086.

Forrester NL, Moss SR, Turner SL, Schirrmeier H, Gould EA (2008) Recombination in rabbit haemorrhagic disease virus: Possible impact on evolution and epidemiology. Virology 376: 390-396.

Forrester NL, Trout R, Turner SL, Kelly D, Boag B, Moss S, Gould EA (2006b) Untravelling the paradox of rabbit haemorrhagic disease virus emergence, using phylogenetic analysis; possible implications for rabbit conservation strategies. Biol Cons 131: 296-306.

Gould AR, Kottenbelt JA, Lenghaus C, Morissy C, Chalmberlain T, Collins BJ, Westbury HA (1997) The complete nucleotide sequencing of rabbit haemorrhagic disease virus (Czech starain V351): use of the polymerase chain reaction to detected replication in Australian Vertebrates and analysis of viral population sequence variation. Virus Res 47: 7-17.

Hukowska-Szematowicz B (2006) Immunological-genetic characteristics of chosen strains of RHD (rabbit haemorrhagic disease) virus. $\mathrm{PhD}$ Thesis. University of Szczecin, Faculty of Natural Science (at the moment Faculty of Biology), Department of Microbiology and Immunology (at the moment Faculty of Immunology), Poland (in Polish).

Hukowska-Szematowicz B, Deptuła W (2010) Phylogenetic analysis of French strains of the RHD virus on the basis of a fragment of gene encoding C-terminal part of structural capsie VP60 protein. $A d v A g-$ ric Science 12: 159-168.

Hukowska-Szematowicz B, Pawlikowska M, Deptuła W (2009) Genetic variability of Czech and German RHD virus strains. Pol J Microbiol 58: $237-245$.

Hurst LD (2009) Genetics and the understanding of selection. Nature Rev Genet 10: 83-93.

Kerr PJ, Kitchen A, Holmes EC (2009) The origin and phylodynamics of rabbit haemorrhagic disease virus. J Virol 83: 12129-12138.

Kinneart M, Linde CC (2010) Capsid gene divergence in rabbit hemorrhagic disease virus. J Gen Virol 91: 174-181.

Le Gall G, Arnauld C, Boilletot E, Morisse JP, Rasschaert D (1998) Molecular epidemiology of rabbit haemorrhagic disease virus outbreaks in France during 1988 to 1995. J Gen Virol 79: 11-16.

Le Gall-Recule G, Zwingelstein F, Boucher S, Le Normand B, Plassiart G, Portejoie Y, Decors A, Bertagnoli S, Guerin JL, Marchandeau S (2011) Detection of a new variant of rabbit haemorrhagic disease virus in France. Vet Rec 168: 137-138.

Le Gall-Recule G, Zwingelstein F, Laurent S, De Boissėson C, Portejoie Y, Rasschaert D (2003) Phylogenetic analysis of rabbit of rabbit haemorrhagic disease virus in France between 1993-2000, and characterization of RHDV antigenic variants. Arch Virol 148: 65-81.

Liu SJ, Xue HP, Pu BQ, Quian NH (1984) A new viral disease in rabbits. Anim Husb Vet Med 16: 253-255.

Marchandeau S, Le Gall-Reculé G, Bertagnoli S, Aubineau J, Botti G, Lavazza A (2005) Serological evidence for a non-protective RHDVlike virus. Vet Res 36: 53-62.

Matiz K, Ursu K, Kecskemeti S, Bajmocy E, Kiss I (2006) Phylogenetic analysis of rabbit haemorrhagic disease virus (RHDV) strains isolated between 1988 and 2003 in eastern Hungary. Arch Virol 151: 1659-1666.

McIntosh M, Behan SC, Mohamed FM, Lu Z, Moran KE, Burrage TG, Neilan JG, Ward GB, Botti G., Capucci L, Metwally SA (2007) A pandemic strain of calcivirus threatens rabbit industries in the Americas. Virol J 4: 96 (doi:10.1186/1743-422X-4-96).

Meyers G, Wirblich C, Thiel HJ (1991) Rabbit haemorrhagic disease virus- molecular cloning and nucleotide sequencing of a calicivirus genome. Virology 184: 664-676.

Meyers G, Wirblich Ch, Thiel HJ, Thumfatr JO (2000) Rabbit haemorrhagic disease virus: Genome organization and polyprotein pro- cessing of a calicivirus studied after transient expression of cDNA constructs. Virology 276: 349-363.

Milton ID, Vlasak R, Nowotny N, Rodak L, Carter MJ (1992) Genomic 3' terminal sequence comparision of Tyree isolates of Rabbit haemorrhagic disease virus. FEMS Microbiol Lett 72: 37-42.

Moss SR, Terner SL, Trout RC, White PJ, Hudson PJ, Desai A, Armesto M, Forrester NL, Gould E (2002) Molecular epidemiology of rabbit haemorrhagic disease virus. J Gen Virol 83: 2461-2467.

Muller A, Freitas J, Silva E, Le Gall-Recule G, Zwingelstein F, Abrantes J, Esteves PJ, Alves PC, van der Loo W, Kolodziejek J, Nowotny N, Thompson G (2009) Evolution of rabbit haemorrhagic disease virus (RHDV) in the European rabbit (Oryctolagus cuniculus) from the Iberian Peninsula. Vet Microbiol 135: 368-373.

Niedźwiedzka-Rystwej P, Pawlikowska M, Hukowska-Szematowicz B, Tokarz-Deptuła B, Deptuła W (2009) Immunological and genetic studies of RHD (rabbit haemorrhagic disease) virus strains. Centr Eur J Immunol 34: 61-67.

Nowotny N, Bascunana CR, Ballagi-Pordany A, Gavier-Widen D, Uhlen M, Belak S (1997) Phylogenetic analysis of rabbit haemorrhagic disease and European brown hare syndrome viruses by comparison of sequences from the capsid protein gene. Arch Virol 142: 657-673.

Oem JK, Lee KN, Roh IS, Lee KK, Kim HR, Park CK, Joo YS (2009) Identification and characterization of rabbit haemorrhagic disease virus genetic variants isolated in Korea. J Vet Med Sci 71: 1519-1523.

Pawlikowska M, Hukowska-Szematowicz B, Deptuła W (2009) Genetical characteristic of six strains of RHD (Rabbit haemorrhagic disease) virus orginating from Europe. Centr Eur J Immunol 34: 7-13.

Pawlikowska M, Hukowska-Szematowicz B, Deptuła W (2010) Phylogenetic analysis of selected strains of Rabbit haemorrhgaic disease virus on the basis of $\mathrm{N}$-terminal fragment of the gene encoding structural protein VP60. Bull Vet Inst Pulawy 54: 129-133.

Rasschaert D, Huguet S, Madelaine MF, Vautherot JF (1995) Sequence and genomic organization of a rabbit hemorrhagic disease virus isolated from a wild rabbit. Virus Genes 9: 121-132.

Schirrmeier H, Reimann I, Köllner B, Granzow H (1999) Pathogenic, antigenic and molecular properties of rabbit haemorrhagic disease virus (RHDV) isolated from vaccinated rabbits: detection and characterization of antigenic variants. Arch Virol 144: 419-735.

Strive T, Wright JD, Robinson AJ (2009) Identification and partial characterization of a new lagovirus in Australian wild rabbits. Virology 384: 97-105.

Strive T, Wright J, Kovaliski J, Botti G, Capucci L (2010) The nonpathogenic Australian lagovirus RCV-1 causes a prolonged infection and elicits protection to rabbit haemorrhagic disease virus. Virology 398: 125-134.

Tian L, Liao J, Li JW, Zhou WR, Zhang XL, Wang HN (2007) Isolation and identification of a non-haemagglutinating strain of rabbit hemorrhagic disease virus from China and sequence analysis for the VP60 gene. Virus Genes 35: 745-752.

Van de Bildt MWG, van Bolhuis GH, van Zijderveld F, van Riel D, Dress JM, Osterhaus ADME, Kuiken T (2006) Cofirmation and phylogenetic analysis of rabbit haemorrhagic disease virus in freeliving rabbits from the Netherlands. J Wildlife Disease 42: 808-812.

Wang W, Hao H, Qiu L, Danf R, Du E, Zhang S, Yand Z (2012) Phylogenetic analysis of rabbit hemorrhagic disease virus in China and the antigenic variation of new strains. Arch Virol 157: 1523-1530.

Wirblich Ch, Thiel HJ, Meyers G (1996) Genetic map of the calicivirus rabbit haemorrhagic disease as deduced from in vitro translation studies. J Virol 70: 7974-7983.

Yang L, Wang F, Hu B, Xue J, Hu Y, Zhou B, Wang D, Xu W (2008) Development of an RT-PCR for rabbit hemorrhagic disease virus (RHDV) and the epidemiology of RHDV in three eastern provinces of China. J Virol Methods 151: 24-29. 